\title{
Sharia supervisory board and social performance of Indonesian Islamic banks
}

\author{
Peni Nugraheni \\ Accounting Department, Universitas Muhammadiyah Yogyakarta, Indonesia \\ Corresponding author e-mail: peninugraheni@yahoo.com
}

A R T I C LE IN F O

\author{
A B S T R A C T
}

Article history:

Available online

Keywords:

Social performance, Sharia

Supervisory Board, characteristics,

Islamic bank

DOI:

https://doi.org/10.20885/jaai.vol22. iss2.art6

\begin{abstract}
This study aims to examine the effect of Sharia Supervisory Board (SSB) characteristics on the level of social performance in Islamic banks in Indonesia. Social function becomes a special feature of Islamic banks that differentiates them from conventional banks. SSB characteristics consist of size, number of meeting, educational qualification, reputation, and cross-membership of SSB members. The data is taken from annual report of Islamic banks in Indonesia for the year 2010-2014 and processed by panel data regression using eviews. The results show that size and reputation of SSB members have significant effect on the social performance while the meeting, educational qualification, and cross membership of SSB members do not have effect on the social performance. The finding also shows that social performance of IBs in Indonesia is relatively high. This study has contribution on the measurement of social performance of Islamic banks and understanding the influence of SSB characteristic on social performance of IBs in Indonesia.
\end{abstract}

\section{Introduction}

Islamic banks (IBs) basically have two functions, namely commercial and social functions. According to Law of The Republic of Indonesia Number 21, 2008 on Sharia banking, the commercial function of IBs can be seen from their role as financial intermediary, which means that they are generally business entities that collecting funds from the community in the form of savings and channeling it to the community in the form of credit and / or other forms in order to improve people's lives. Social function of IBs refers to bank responsibility for the wellbeing of all stakeholders (Al-shamali, Sharif, \& Irani, 2013). Social function becomes a special feature of Islamic banks that differentiates them from conventional banks. According to Haniffa and Hudaib (2007), IBs perform their social function throught their contribution in managing social funds such as zakah, saddaqa and qardul hassan. Islamic banks' social function shows their contribution to community welfare while helping Muslims fulfill their religious obligations (Maali, Casson, \& Napier, 2006).

Performance of Islamic bank can be influenced by several factors, among other is sharia supervisory board (SSB). Sharia supervisory board (SSB) is one of the main part of corporate governance in Islamic bank (IB) that should be disclosed as a form of social reporting in their annual report. The role of SSB is to ensure that the activity of IBs is according to Sharia principles. The Sharia principles encourages organization to behave just, fair and promote the ethical norms to all the people involved in business transactions (Hafeez, 2013). According to Hameed et al. (2004), strong CG encourages the achievement of the roles and contributions of IBs in economic activities. Setiawan (2009) argues that SSB are stakeholders who are concern with the role of Islamic banks, including in social function as a contribution to economic development, social environment, stakeholder and public education. Therefore, how IB carries out social functions also become the attention of SSB.

Previous studies show the different results related to the influence of SSB on IB's performance (Farook, Hassan, \& Lanis, 2011; Rahman \& Bukair, 2013; Mollah \& Zaman, 2015; Almutairi \& Quttainah, 2017; Nomran, Haron, \& Hassan, 2018). The quality of the SSB members are determined by several factors i.e. educational background, size, reputation, cross-membership, and the frequencies of meeting (Farook, Hassan, \& Lanis, 2011; Rahman \& Bukair, 2013). Those factors are used to determine the supervising level of SSB to IBs performance. The argument is inline with their research finding that SSB characteristics have association with financial or social performance.

This study aims to examine the effect of SSB characteristics on the level of social performance in Islamic banks in Indonesia. The importance of this research can be seen from several aspects, first, social function is one of the differentiators between Islamic banks and conventional banks, even becoming the identity of Islamic banks. Islamic banks will always be appreciated by the public as long as they can consistently maintain their 
identity, which is always in accordance with sharia and show superior ethical and moral values in their activities (Haniffa \& Hudaib, 2007). Evaluating performance of Islamic financial institutions is important to measure the achievement of the management in keeping amanah from the shareholders and the Ummah. The management of Islamic financial institution is not only responsible to the stakeholders, but most importantly is how they conduct their business in order to ensure that all the activities are in accordance with the sharia principles. Social function of Islamic banks strengthens their contribution to the community and society. However, there are still few studies related to the social performance measurement of Islamic banks, such as Samad and Hassan (1999); Hameed et al. (2004); Haniffa and Hudaib (2007); Setiawan (2009); and Asutay and Harningtyas (2015).

Second, there is an increase in public awareness to see the contribution of the Islamic business entities on society and environment (Amran et al., 2017). In Indonesia, the community has the greatest influence for an organization to disclose CSR disclosure (Gunawan, 2015). Disclosure of social activities in the annual report is one tool to provide information on company activities to the community so that the community can assess organizational performance. Third, there are various indexes for measuring banking performance (Samad \& Hassan, 1999). Previous researches usually use index of corporate social responsibility or Islamic social reporting disclosure to measure social performance (Darus et al., 2014; Junaidi, 2015; Amran et al., 2017). This study uses different measurement by adopting performance ratio of social contribution expenditure described by Samad and Hassan (1999); Hameed et al. (2004); and Setiawan (2009). This study is expected to give contribution to: (a) measure social performance of Islamic banks in Indonesia based on certain measurement and (b) understand the influence of SSB role in social performance of IBs in Indonesia.

This study consists of five sections. Section two explains the literature review related to stakeholder theory, social performance of Islamic banks, sharia supervisory board and hypotheses development. Section three describes the methodology of this study and section four discusses the statistical result including the logical reasons behind the results. Last section is conclusion, limitation of the study and suggestion for the future study.

\section{Literature Review}

\section{Stakeholders Theory}

Freeman (2004) defines stakeholder as "any group or individual that can affect or is affected by the achievement of a corporation's purpose". This theory emphasizes the role of companies to always have good relationships with parties related to the organization and thus, their interests must be balanced (Freeman, 2004). Organizations need to identify who stakeholders that have relationships with them. This is important because it has consequences related to ethical, policy, and strategic conclusions (Fontaine, Haarman, \& Schmid, 2006).

For IFIs, their stakeholders includes depositors, shareholders, government, employees, management, suppliers and society (Rahman \& Bukair, 2013). IFIs not only provide services to various stakeholders, but also must ensure that their activities are in accordance with sharia (Hameed et al., 2004). According to Farook, Hassan, and Lanis (2011), compliance with sharia can maintain the confidence of shareholders and other stakeholders during engaging in Islamic financing activities. Measuring the sharia compliance and social responsibility disclosure of Islamic banks are useful for evaluating the performance of Islamic banks to bind the relationship between IFIs and their stakeholders (Hameed et al., 2004).

\section{Social performance of Islamic Bank}

Islamic banks are established to provide the need of Muslim in financial services that accordance to Islamic principles. There are five aspects that differentiate Islamic Banks (IBs) from conventional banks (Haniffa \& Hudaib, 2007): (a) philosophy and basic values; (b) interest-free products and services; (c) provisions regarding transaction that accordance to Islamic principles, (d) focus on developmental and social goals; and (e) having the Sharia Supervisory Board (SSB).

Social goal refers to the nature of social justice and accountability (Farook, Hassan, \& Lanis, 2011). Haniffa and Hudaib (2007) assert that Islamic banks are expected to be more socially responsible than their conventional counterparts, as Islam emphasizes on social justice. There are many examples of social justice practices that are emphasised by Islam such as the avoidance of usury (riba), the religious tax (zakah) and interestfree loans (qardhul hasan) (Rahman \& Bukair, 2013). Social justice can also be demostrated through the provision of the truly Islamic financial modes of lending namely mudharabah and musharakah (Samad \& Hassan, 1999). Thus, social responsibility disclosures are important to actually reflect how the institutions discharge their contracts with a group of stakeholders (Hameed et al., 2004). Financial and social dimension construct the nature of Islamic banks to produce an ethical financial system (Asutay \& Harningtyas, 2015). 
Saridona and Cahyandito (2015) investigate the social performance of Indonesian Islamic banks using ISR index from Othman and Thani (2010) that consist of 43 items. The result shows that IBs social performance is in good category with social performance index of $61.73 \%$. On the other hand, Mukhibad, Kiswanto, and Jayanto (2017) examine the factors influencing financial and social performance of Islamic Banks in Indonesia. Social performance is measured using zakah performance (ZP) and qardhul hasan $(\mathrm{QH})$ while financial performance is measured using ROA and ROE. The results show that implementation of good corporate governance (with proxy of Islamic GCG Disclosure index), company size and FDR have significant influence on ROA, ZP and QH.

\section{Sharia Supervisory board (SSB)}

Sharia Supervisory board (SSB) is one of the main organs in Islamic banks (IBs) to ensure that the activity of IBs is accordance to Islamic principles. To encourage the effectiveness of SSB role, Indonesian Central Bank (BI) issues regulation Number 11/33/PBI/2009 concerning The Implementation of Good Corporate Governance by Islamic Commercial Banks and Islamic Business Units that describes the responsbilities of SSB. According to the regulation, SSB has reponsibility as follows: (a) assessing and ensuring the compliance to Sharia Principles on operational guidelines and products issued by the bank; (b) supervising the process of developing new products to be conformed with the fatwa of the National Sharia Council - Indonesian Ulema Council (DSN-MUI); (c) requesting a fatwa from DSN-MUI for new banking products that having no fatwa yet; (d) periodically reviewing the fulfillment of Sharia Principles on the mechanism for raising funds and channeling funds and banking services; and (e) requesting data and information related to sharia aspects from Islamic banking division in carrying out its duties.

Bank Indonesia also provides provision on requirement of becoming SSB members. According to Regulation of Bank Indonesia Number 6/24/PBI/2004 concerning Commercial Bank Conducting Business Based on Sharia Principles, there are requirements in determining candidates for the SSB members, among others: (a) integrity, SSB members must have good character and morals, commitment to comply with Islamic banking regulations and other laws, commitment to the development of a healthy and sustainable bank, and they are not included in the list of non-graduated as stipulated in provisions regarding fit and proper tests determined by BI, (b) Competence, they must have knowledge and experience in the field of sharia muamalah as well as knowledge in the field of banking and finance, (c) Financial reputation, they are at least not included in the list of bad loans and have never been declared bankrupt or become a shareholder, member of the board of commissioners, or board of directors who found guilty of causing a company to go bankrupt within the last five years before being nominated.

Previous studies related to SSB and IB performance have been conducted by several scholars. Almutairi and Quttainah (2017) examine the effect of SSB characteristics on the financial performance of 82 IBs from 15 countries for the year 1993-2014 and find that size, the number of outside member of SSB, SSB interlock, SSB membership in IFSB, expertise, and SSB education have positive and significant impact on IB performance. Nomran, Haron, and Hassan (2018) who study the relationship between SSB characteristics and IBs performance in Malaysia find that the size, cross membership, and reputation has positive relationship while educational qualification, expertise and change in the board composition have negatively influence IBs performance.

\section{Hypotheses}

Hameed et al. (2004) argue that characteristics of SSB can enhance the integrity of the board in order to increase the confidence level of stakeholders toward IBs. Those characteristics can be represented by some indicators to measure the relationship between SSB characteristics and social performance (Farook, Hassan, \& Lanis, 2011; Rahman \& Bukair, 2013). This study develops hypotheses related to the influence of SSB characteristics toward social performance of Islamic banks as follows:

\section{SSB Size and social performance of IBs}

The Indonesian regulation states that the number of members of the Sharia Supervisory Board is at least 2 (two) people or a maximum of $50 \%$ (fifty percent) of the total members of the Board of Directors. Greater number of SSB members are expected to be more intense in monitoring activities to ensure that IBs activities are in accordance with Islamic principles including the commitment of Islamic banks to carry out their social functions. Therefore, it is expected that the social performance of IBs is also higher. Rahman and Bukair (2013), Almutairi and Quttainah (2017), and Nomran, Haron, and Hassan (2018) state that SSB size has a positive effect on IBs performance. Therefore, this study develop hypothesis as follows:

H1: SSB size has positive effects on social performance of IBs 


\section{SSB meeting and social performance of IBs}

The meeting is used for SSB to discuss and determine the suitability between the activities and products of IBs with Islamic principles. The disclosure of the number of SSB meeting assures that SSB has doing the job in supervising IBs activities (Hameed et al., 2004). The number of SSB meeting will have influence in the implementation of IBs activities, including social activities that will be visible in the disclosure of annual report. Grassa and Matoussi (2014) find that SSB meeting in GCC countries is higher than in Southeast Asia countries (15 meetings per years comparing to 11 times per years for Southeast Asia banks).

In Indonesia, SSB should have meeting at list once in a month (BI, 2009). The greater number of SSB meeting will impact on the level of social performance of IBs. Naseem et al. (2017) examine the relationship between board characteristics and CSR disclosure and find that the board meeting has positive impact on CSR disclosure. Therefore, the hypothesis is as follows:

$\mathrm{H} 2$ : the number of SSB meeting has positive effects on social performance of IBs

\section{Educational qualification of SSB members and social performance of IBs}

The education degree is expected to influence the level of knowledge of human being. Supervising Islamic banking industry needs knowledge such as Islamic law, economics, and financial and accounting practice (Rahman \& Bukair, 2013). According to the regulation of Bank Indonesia, SSB members must have competency that related to the knowledge and experience in the field of sharia muamalah and in the field of banking and finance. SSB members with high level education will enable them to solve not only sharia problem but also economic problems (Rahman \& Bukair, 2013). Therefore, SSB members with a doctorate degree in business and economics will have better performance in doing their role in supervising the IBs performance, including social performance (Almutairi \& Quttainah, 2017; Farook, Hassan, \& Lanis, 2011).

Based on the explanation above, the hypothesis of this study is as follows:

H3: Educational qualification of SSB members has positive effects on social performance of IBs

\section{The reputation of SSB members and social performance of IBs}

There are factors that influence the appointment of nominees for particular position, namely relevant skills, business experience and reputation (Hussain \& Mallin, 2003). Therefore, the selection of SSB members who have been involved in Islamic banking and financial sharia board institutions is preferred by IFIs (Rahman \& Bukair, 2013). In Indonesia, SSB members are elected by the board of director of IBs and must get recommendation from Indonesian Ulema Council (MUI). IB then asks an approval to the Bank Indonesia for SSB members nominees that have received a recommendation from the MUI. The General Meeting of Shareholders appoints SSB members who have received recommendations from MUI and approval from Bank Indonesia.

A good reputation and sufficient knowledge of Islamic law is one of the considerations in choosing SSB members (Rahman \& Bukair, 2013). Choosing a reputable SSB member is expected to improve the performance of IBs in complying with Islamic principles, including better social performance. Nomran, Haron, and Hassan (2018) find that SSB reputation has positively influence to IBs performance. Therefore, this study develops hypothesis: H4: Reputation of SSB members has positive effects on social performance of IBs

\section{Cross membership of SSB and social performance of IBs}

Indonesia regulation states that SSB members may become SSB members in other IFIs, with maximum in four IFIs. SSB members must disclose their cross membership in the annual report as a form of transparency. Cross membership can expose more discussion on application of Islamic law in IBs (Farook, Hassan, \& Lanis, 2011). Further, it increase the experience about implementation of activities and products and services of IBs that accordance to Islamic principles.

Rahman and Bukair (2013) state that cross membership will influence the CSR disclosure. The argument is supported by Nomran, Haron, and Hassan (2018) who find that SSB cross membership has better association with banking performance. Therefore, this study develops the hypothesis:

H5: Cross membership of SSB members has positive effects on social performance of IBs

\section{Research Method}

The population is all Islamic banks in Indonesia. This study uses purposive sampling and consists of Islamic banks which provide all data needed by this study. Islamic banks used in this study are full-fledge Islamic banks and Islamic windows. This study use five years annual reports from 2010-2014 that will be downloaded from official website of each Islamic Bank. 
Dependent variable in this study is social performance of Islamic banks in Indonesia. This variable is measured by performance ratios as proposing by Samad \& Hassan (1999), Hameed et al. (2004), and Setiawan (2009). There are four themes namely contribution to economic development, to society and social environment, to their stakeholders, and to education of human resources.

a. The contribution of economic development is represented by the ratio of profit sharing modes of financing and the intencity of agency roles of Islamic banking. The formulas of both ratios are below:

$$
\begin{gathered}
\text { The Ratio of Profit Sharing Modes } \\
\text { of Financing to Total Financing MMR }
\end{gathered}=\frac{\text { Mudharabah }+ \text { Musharakah }}{\text { Total Financing }}
$$

The criteria for calculating MMR ratio is as follow: Score $5=$ MMR $>50 \%$; Score $4=40 \%<$ MMR $\leq$ $50 \%$; Score $3=30 \%<$ MMR $\leq 40 \%$; Score $2=20 \%<$ MMR $\leq 30 \%$; and Score $1=$ MMR $\leq 20 \%$.

$$
\text { The Intencity of Agency Roles of Islamic banking }(\text { IAR })=\frac{\text { Mudharabah Deposit (URIA) }}{\text { Total Funding }}
$$

The criteria for calculating AR ratio is as follow: Score $5=$ IAR $>90 \%$; Score $4=80 \%<$ IAR $\leq 90 \%$; Score $3=70 \%<$ IAR $\leq 80 \%$; Score $2=60 \%<$ IAR $\leq 70 \%$; and Score $1=\operatorname{IAR} \leq 60 \%$.

b. The contribution to the society is represented by the ratio of qardh financing and zakah performance. The formulas of both ratios will be explaines below:

$$
\text { The Ratio of Qardh Financing }(\mathrm{QR})=\frac{\text { Qardh Financing }}{\text { Total Financing }}
$$

The criteria for calculating QR ratio is as follow: Score $5=\mathrm{QR}>5 \%$; Score $4=3 \%<\mathrm{QR} \leq 5 \%$; Score 3 $=2 \%<\mathrm{QR} \leq 3 \%$; Score $2=1 \%<\mathrm{QR} \leq 2 \%$; and Score $1=\mathrm{QR} \leq 1 \%$.

$$
\text { The Ratio of Zakah Performance }(Z R)=\frac{\text { Zakah Distribution }}{\text { Profit before Tax }}
$$

The criteria for calculating ZR ratio is as follow: Score $5=Z R>2,5 \%$; Score $4=2 \%<Z R \leq 2,5 \%$; Score $3=1,5 \%<\mathrm{ZR} \leq 2 \%$; Score $2=1 \%<\mathrm{ZR} \leq 1,5 \%$; and Score $1=\mathrm{ZR} \leq 1 \%$.

c. The contribution to the stakeholders is represented by the ratio of the contribution to Mudharib and the contribution to the Mudharabah Mutlaqah Invesment Account Holders. The formulas of both ratios will be explaines below:

$$
\text { The Contribution to Mudhorib }(\mathrm{CM})=\frac{\text { Wages Expenses and Other Welfares }}{\text { Operational Revenue }}
$$

The criteria for calculating CM ratio is as follow: Score $5=\mathrm{CM}>15 \%$; Score $4=12 \%<\mathrm{CM} \leq 15 \%$; Score $3=9 \%<\mathrm{CM} \leq 12 \%$; Score $2=6 \%<\mathrm{CM} \leq 9 \%$; and Score $1=\mathrm{CM} \leq 6 \%$.

$$
\text { The Contribution URIA Holders }(\mathrm{CUH})=\frac{\text { Revenue Sharing Distribution }}{\text { Total Mudharabah Mutlaqah Investment }}
$$

The criteria for calculating $\mathrm{CUH}$ ratio is as follow: Score $5=\mathrm{CUH}>15 \%$; Score $4=12 \%<\mathrm{CUH} \leq$ $15 \%$; Score $3=9 \%<\mathrm{CUH} \leq 12 \%$; Score $2=6 \%<\mathrm{CUH} \leq 9 \%$; and Score $1=\mathrm{CUH} \leq 6 \%$.

d. The contribution to the increasing capacity of human resources is represented by the ratio of the contribution to human resources development. The formulas of both ratios will be explaines below:

The Contribution to Human Resources Develepment $($ CHRD $)=\frac{\text { Education and Training Expenses }}{\text { Profit after Tax }}$

The criteria for calculating CHRD ratio is as follow: Score $5=$ CHRD $>15 \%$; Score $4=12 \%<$ CHRD $\leq$ 15\%; Score $3=9 \%<$ CHRD $\leq 12 \%$; Score $2=6 \%<$ CHRD $\leq 9 \%$; and Score $1=$ CHRD $\leq 6 \%$. 
Finally, the formula of social performance (SP) is:

$$
S P=\frac{\text { Total Score }}{35} \times 100 \%
$$

Independent variables used in this study are SSB characteristics. The characteristics consist of the size, meeting, educational qualification, reputation and cross membership of SSB members. The measurement of those variables are described in Table 1.

Table 1. Independent Variables Measurement

\begin{tabular}{ll}
\hline \multicolumn{1}{c}{ Independent Variables } & \multicolumn{1}{c}{ Definiton } \\
\hline SSB Size & total number of SSB members \\
SSB meeting & total number of SSB meeting in a year \\
Educational qualification of SSB members & proportation of PhD holders in the Sharia supervisory board \\
Reputable SSB members & $\begin{array}{l}\text { Proportion of SSB members that have position in the Sharia } \\
\text { National Board (DSN-MUI) } \\
\text { pross membership of SSB members } \\
\text { Islamic financial institutions as a member of SSB }\end{array}$ \\
\hline
\end{tabular}

The data of this study will be processed using panel regression model. The panel regression model is used to find out the most efficient model from the three equation models, namely the Common Effect Model (CEM), Fixed Effect model (FEM) and Random Effect Model (REM) using eviews software.

The regression equation is as follow:

SP $=\alpha+\boldsymbol{\beta}_{\mathbf{1}}$ Size $+\boldsymbol{\beta}_{\mathbf{2}}$ Meet $+\boldsymbol{\beta}_{\mathbf{3}}$ Edu $+\boldsymbol{\beta}_{\mathbf{4}}$ Rep $+\boldsymbol{\beta}_{\mathbf{5}}$ Cross $+\mathrm{e}$

Where:

SP Social Performance of Islamic bank

$\alpha \quad$ Intercept

$\beta \quad$ Slope

Size SSB Size

Meet SSB Meeting

Edu Educational qualification of SSB

Rep Reputation of SSB members

Cross Cross membership of SSB members

e error term

\section{Results and Discussion}

There are 12 full fledge Islamic banks and 22 Islamic windows per December 2014. Because of the availability data, there are $75(44.12 \%)$ annual reports from total of 170 annual reports for five years that can be processed further due to the completeness of information.

Table 2 describes descriptive statistical tests conducted in this study. The descriptive statistical test aims to determine the mean, minimum, maximum and standard deviation of the variables studied. Based on Table 2, the average value of social performance is 0.653467 , SSB size is 2.666667, SSB meeting is 14.61333, education qualification is 0.582800 , SSB reputation is 0.326 , and cross membership is 0.571733 .

The descriptive result of social performance shows that the average value is $65.35 \%$ and it indicates a high enough performance. This is good indicator that IBs in Indonesia has carry out their social roles and disclose them in annual report. Islamic community has the right to know how the bank participates in helping the poor and needy (Maali, Casson, \& Napier, 2006). The result supports the research by Setiawan (2009) who states that social performance of two Islamic banks in Indonesia have average more than 50\%, and Saridona \& Cahyandito (2015) who find that social performance of IBs is in good category with index of $61.73 \%$. While Samad and Hassan (1999) finds that IBs in Malaysia have low performance in community financing. This financing is considered unprofitable and riskier compared to other alternative modes of financing. 
Table 2. Descriptive Statistic

\begin{tabular}{lcccccc}
\hline & SP & Size & Meet & Edu & Rep & Cross \\
\hline Mean & 0.653467 & 2.666667 & 14.61333 & 0.582800 & 0.326000 & 0.571733 \\
Median & 0.690000 & 3.000000 & 13.00000 & 0.670000 & 0.330000 & 0.670000 \\
Maximum & 0.890000 & 3.000000 & 40.00000 & 1.000000 & 1.000000 & 1.000000 \\
Minimum & 0.310000 & 2.000000 & 4.000000 & 0.000000 & 0.000000 & 0.000000 \\
Std. Dev. & 0.117283 & 0.474579 & 5.082810 & 0.337709 & 0.336420 & 0.360118 \\
Skewness & -0.381074 & -0.707107 & 1.887540 & -0.379748 & 0.738998 & -0.371155 \\
Kurtosis & 2.656975 & 1.500000 & 10.04534 & 2.140681 & 2.472858 & 1.910264 \\
& & & & & & \\
Jarque-Bera & 2.182922 & 13.28125 & 199.6499 & 4.110199 & 7.694844 & 5.432961 \\
Probability & 0.335726 & 0.001306 & 0.000000 & 0.128080 & 0.021335 & 0.066107 \\
Sum & & & & & & \\
Sum Sq. Dev. & 1.017899 & 16.66667 & 1911.787 & 8.439512 & 8.375200 & 9.596675 \\
Observations & 75 & 75 & 75 & 75 & 75 & 75 \\
\hline
\end{tabular}

Three methods of panel regression is tested to determined the right method for analyzing the data. After comparing the result of these three models (Common Effect Model, Fixed Effect model and Random Effect Model), the right model used in this study is panel regression with random effect model (REM). The regression result of REM can be seen in the Table 3.

Table 3. Regression Result of Random Effect Model

Dependent Variable: Y

Method: Panel EGLS (Cross-section random effects)

Sample: 20102014

Periods included: 5

Cross-sections included: 15

Total panel (balanced) observations: 75

Swamy and Arora estimator of component variances

\begin{tabular}{|c|c|c|c|c|}
\hline Variable & Coefficient & Std. Error & t-Statistic & Prob. \\
\hline $\mathrm{C}$ & 0.367909 & 0.094552 & 3.891060 & 0.0002 \\
\hline Size & 0.084987 & 0.029402 & 2.890471 & 0.0051 \\
\hline Meet & -0.000739 & 0.002392 & -0.308976 & 0.7583 \\
\hline Edu & 0.089892 & 0.048538 & 1.851976 & 0.0683 \\
\hline Rep & 0.205420 & 0.059692 & 3.441315 & 0.0010 \\
\hline Edu & -0.086805 & 0.049983 & -1.736687 & 0.0869 \\
\hline \multicolumn{5}{|c|}{ Effects Specification } \\
\hline & & & S.D. & Rho \\
\hline Cross-section random & & & 0.050743 & 0.2677 \\
\hline Idiosyncratic random & & & 0.083933 & 0.7323 \\
\hline \multicolumn{5}{|c|}{ Weighted Statistics } \\
\hline R-squared & 0.294852 & bendent var & & 0.388620 \\
\hline Adjusted R-squared & 0.243754 & endent var & & 0.095383 \\
\hline S.E. of regression & 0.082947 & ared resid & & 0.474734 \\
\hline F-statistic & 5.770351 & Jatson stat & & 1.348442 \\
\hline \multirow[t]{2}{*}{ Prob (F-statistic) } & 0.000166 & & & \\
\hline & \multicolumn{4}{|c|}{ Unweighted Statistics } \\
\hline R-squared & 0.410854 & bendent var & & 0.653467 \\
\hline Sum squared resid & 0.599691 & Jatson stat & & 1.067467 \\
\hline
\end{tabular}


Table 3 shows the results of the panel regression. The adjusted R square has value $24.37 \%$. It means that SSB characteristics can explain social performance in amount of $24.37 \%$ while $75.63 \%$ is explained by other variables which not examined in this study. All independent variables (SSB characteristic) has significant influence toward social performance of Islamic banks with sig. value of $0.000166<$ sig. value 0.05 .

Further, the influence of each SSB characteristics toward social performance of IBs can be described below:

\section{SSB size and social performance of Ibs}

Table 3 indicates that SSB size has a regression coefficient of 0.084987 with a significance value of $0.0051<$ alpha 0.05. It means that SSB size has a positive effect on social performance of IBs in Indonesia. Therefore, H1 is accepted. This result is similar with the studies by Almutairi and Quttainah (2017) and Nomran, Haron, and Hassan (2018). SSB with larger member will have higher knowledge and experience (Rahman \& Bukair, 2013). Almutairi and Quttainah (2017) argue that larger SSB members indicates the better network and connection as well as more expertise which can influence bank performance.

\section{SSB meeting and social performance of IBs}

SSB meeting has a regression coefficient -0.000739 and significant value of $0.7583>$ alpha 0.05 . This study finds that SSB meeting has negative non-significant effect on social performance of IBs. Therefore, $\mathrm{H} 2$ is rejected. The result does not support the research of Naseem et al. (2017).

The meeting of SSB has average 14, 61 times per year, with minimum value of 4 and maximum value of 40 meetings. The average number is higher the the requirement to have a minimum meeting of once in one month or twelve meetings per year. However, the high number of meeting cannot influence the level of social performance. Based on the data from the annual report, there are SSBs who hold meeting less than 12 times a year. Further, not all meeting can be attended by all SSB members. IBs mostly do not explain the reasons why some SSB members cannot attend the meeting. According to Muneeza and Hassan (2014), the quality of decision by SSB members may be low when they are not present in organization. There is possibility that SSB members do meeting when they are invited by the directors for specific purpose (Muneeza \& Hassan, 2014) or just fulfill the minimum requirement of the number of SSB meeting. This condition may make the social performance is not a priority for discussion of the meeting of SSB or management of IBs. The high number of meeting will result on higher coordination cost and the board member may split the agenda between various meeting without expanding the certain agenda (Dienes \& Velte, 2016). Therefore, the meeting does not affect the level of social performance of IBs.

\section{Educational qualification of SSB members and social performance}

The regression result of the influence of educational qualification of SSB members on social performance shows the coefficient value is 0.089892 and significant value is $0.0683>$ alpha 0.05 . The result indicates that educational qualification of SSB members has no effect on social performance of IBs. Thus, $\mathrm{H} 3$ is rejected.

This study has different result with Nomran, Haron, and Hassan (2018) who find that SSB members' education has positive and significant effect on IBs performance. Nomran, Haron, and Hassan (2018) uses postgraduate degree as proxy to measure the educational background of SSB while this study uses doctoral degree. The average of this variable is $58.3 \%$ showing that the educational level of SSB members is high. Unfortunately, this condition can not influence the social performance of IBs. Farook, Hassan, and Lanis (2011) argue that SSB with a doctorate degree in business and economics can inform the development of IBs' practice. The expertise of SSB with business knowledge will influence IBs performance (Nomran, Haron, \& Hassan, 2018). The data shows that most of PhD holders of SSB members have expertise on sharia muamalah than business knowledge. It may impact on focus on SSB to the detail of transaction that accordance to sharia principles rather than evaluate the social performance of IBs.

\section{Reputation of SSB members and social performance of IBs}

Table 3 shows that the reputation has coefficient value 0.0205420 and significant value $0.0010<$ alpha 0.05 . The study concludes that reputation of SSB members has positive and significant effect on social performance of IBs. Therefore, H4 is accepted. The study is inline with Farook, Hassan, and Lanis (2011) and Nomran, Haron, and Hassan (2018) who find that SSB reputation has positively influence the IBs performance. The position of of SSB members in DSN-MUI may enhance the performance of SSB to more concern on social contribution of Islamic banks. 


\section{Cross membership of SSB members and social performance of IBs}

The coefficient and significant value of cross membership are -0.086805 and $0.0869>$ alpha 0.05 . The result indicates that $\mathrm{H} 5$ is rejected because cross membership of SSB members has no effect on social performance of IBs. This result is different with the study by Rahman and Bukair (2013), Almutairi and Quttainah (2017), and Nomran, Haron, and Hassan (2018). The average of cross membership is $57.2 \%$ indicating that more than half of SSB members become SSB in other IFIs. However, the statistical test indicates that H5 is rejected. This result may have correlation with the result of $\mathrm{H} 2$ and $\mathrm{H} 3$. Cross membership in other IFIs and position in DSN-MUI may increase the busyness of the SSB members, and therefore some members may not be able to attend the SSB meeting. It may impact on the supervision level related to the social performance of IBs. Thus, large or small social performance depends more on the commitment of the IBs themselves.

\section{Conclusion}

The position of SSB is very crucial in the Islamic banks. The role of SSB is to make sure that the activities of Islamic banks always in line with Sharia principles. Thus, SSB is also expected to support the social performance of Islamic banks in order to maintain IBs contribution to the Muslim ummah and their stakeholders. This study examines the influence of SSB members on the social performance of IBs. Based on the statistical test of panel data regression, the size and reputation of SSB members has significant effect on the social performance. The other characteristics (the meeting, educational qualification, and cross membership of SSB members) do not have effect on the social performance. The finding also shows that social performance of IBs in Indonesia is relatively high.

For practical impications, this study provides the desciption of SSB characteristics in Indonesian IBs. This study indicates that some characteristics of SSB do not influence the level of social performance in IBs although in general, SSB has obeyed the regulation of Bank Indonesia in term of corporate governance in Islamic banks. These results should become the attention for all parties, especially those directly related to IBs (i.e. management, regulator). The regulator can encourage the strengthening of SSB role through improving SSB policy. For example, the provision of SSB meeting is not only determined by the number of meetings, but also the obligation for each SSB members to attend those meetings. The meeting can be used to discuss the performance of IBs including how they carry out their social performance. The social function is one of the main role of IBs. Therefore, Islamic banks should realize this important function without waiting for encouragement from the SSB. However, the high social performance must be maintained and even enhanced to perform the commitment of IBs on social contribution and in the religious life of society.

This study has several limitation. First, the lack of availability data, specifically the data from Islamic windows. Although they have separation annual report from their conventional banks, but not all IBs provide clear and complete information. Second, the measurement of social performance is limited to the certain items adopted from previous researches. The measurement may can be added by other items such as the level of welfare of many stakeholder or contribution to the economic distribution to make it more comprehensive measurement. Third, the study focuses on SSB characteristics in Indonesian IBs. Other countries may have different mechanism on how the SSB supervising IBs, and therefore, the result can not be compared to the other countries that have different SSB mechanism.

Future studies can improve the limitation of this study through the broader samples and items of measurement. Therefore, to what extent the social performance of IBs around the word can be mapping to strengthen the contribution of IBs in the society.

\section{References}

Al-Shamali, F. A., Sharif, A., \& Irani, Z. (2013). Islamic banking reinterpretation of the stakeholder theory. Arabian Journal of Business and Management Review (OMAN Chapter), 3(2), 63-71.

Almutairi, A. R., \& Quttainah, M. A. (2017). Corporate governance: evidence from Islamic banks. Social Responsibility Journal, 13(3), 601-624.

Amran, A., Fauzi, H., Purwanto, Y., Darus, F., Yusoff, H., Zain, M. M., Naim, D. M. A., and Nejati, M. (2017). Social responsibility disclosure in Islamic banks : a comparative study of Indonesia and Malaysia. Journal of Financial Reporting and Accounting, 15(1), 99-115.

Asutay, M., \& Harningtyas, A. F. (2015). Developing maqasid al-shari'ah index to evaluate social performance of 
Islamic banks: a conceptual and empirical attempt. International Journal of Islamic Economics and Finance Studies, 1(1), 5-64.

Bank Indonesia (2004). Regulation of Bank Indonesia number 6/24/PBI/2004 concerning commercial bank conducting business based on sharia principles. Retrieved October 20, 2015, from https://www.ojk.go.id/Files/201402/pbi062404_eng_1392970316.pdf

Bank Indonesia (2009). Regulation of Bank Indonesia number 11/33/PBI/2009 concerning the implementation of good corporate governance by islamic commercial banks and Islamic business unit. Retrieved October 20, 2015, from https://www.ojk.go.id/Files/regulation/banking/bir/2009/ pbi113309_eng.pdf

Dienes, D., \& Velte, P. (2016). The Impact of Supervisory Board Composition on CSR Reporting. Evidence from the German Two-Tier System. Sustainability, 8(64), 1-20.

Farook, S., Hassan, M. K., \& Lanis, R. (2011). Determinants of corporate social responsibility disclosure: the case of Islamic banks. Journal of Islamic Accounting and Business Research, 2(2), 114-141.

Fontaine, C., Haarman, A., \& Schmid, S. (2006). The stakeholder theory. Retrieved February 20, 2017, from https://pdfs.semanticscholar.org/606a/ 828294dafd62aeda92a77bd7e5d0a39af56f.pdf

Freeman, R. E. (2004). The stakeholder approach revisited. Zeitschrift Für Wirtschafts- Und Unternehmensethik, 5(3), 228-254.

Grassa, R., \& Matoussi, H. (2014). Corporate governance of Islamic banks a comparative study between GCC. International Journal of Islamic and Middle Eastern Finance and Management, 7(3), 346-362.

Gunawan, J. (2015). Corporate social disclosures in Indonesia: stakeholders ' influence and motivation. Social Responsibility Journal, 11(3), 535-552.

Hafeez, M. M. (2013). An analysis of corporate governance in Islamic and western. International Journal of Business, Economics and Law, 2(3), 98-103.

Hameed, M. I. S., Wirman, A., Alrazi, B., Mohd Nazli, bin M. N., \& Pramono, S. (2004). Alternative disclosure and performance measures for Islamic banks. Kuala Lumpur.

Haniffa, R., \& Hudaib, M. (2007). Exploring the ethical identity of Islamic banks via communication in annual reports. Journal of Business Ethics, 76, 97-116.

Hussain, S. H., \& Mallin, C. (2003). The dynamics of corporate governance in Bahrain: structure, responsibilities and operation of corporate boards. Corporate Governance: An International Review, 11(3), 249-261.

Junaidi. (2015). Analisis Pengungkapan CSR Perbankan Syariah di Indonesia Berdasarkan Islamic Social Reporting Index. Journal of Accounting and Investment, 16(1), 75-85.

Maali, B., Casson, P., \& Napier, C. (2006). Social reporting by Islamic banks. ABACUS, 42(2), 266-289.

Mollah, S., \& Zaman, M. (2015). Shari'ah supervision, corporate governance and performance: conventional vs Islamic banks. Journal of Banking and Finance, 58, 418-435.

Mukhibad, H., Kiswanto, \& Jayanto, P. Y. (2017). An analysis on financial and social performance of Islamic banks in Indonesia. International Journal of Monetary Economics and Finance, 10(3/4), 295-308.

Muneeza, A., \& Hassan, R. (2014). Shari'ah corporate governance: the need for a special governance code. Corporate Governance, 14(1), 120-129.

Naseem, M. A., Riaz, S., Rehman, R. U., Ikram, A., \& Malik, F. (2017). Impact of board characteristics on corporate social responsibility disclosure. Journal of Applied Business Research, (July/Agustus), 799808.

Nomran, N. M., Haron, R., \& Hassan, R. (2018). Shari'ah supervisory board characteristics effects on Islamic banks' performance: evidence from Malaysia. International Journal of Bank Marketing, 36(2), 290-304.

Othman, R., \& Thani, A. M. (2010). Islamic social reporting of listed companies in Malaysia. International Business \&Economic Research Journal, 9(4), 135-144.

Rahman, A. A., \& Bukair, A. A. (2013). The influence of the shariah supervision board on corporate social responsibility disclosure by Islamic banks of Gulf co-operation council countries. Asian Journal of 
Business and Accounting, 6(2), 65-104.

Republic of Indonesia. (2008). Law of the Republic of Indonesia number 21 year 2008 on sharia banking. Retrieved October 20, 2015, from https://www.ojk.go.id/en/ kanal/syariah/regulasi/undangundang/Documents/ 974.pdf

Samad, A., \& Hassan, M. K. (1999). The perfomance of Malaysian Islamic bank during 1984-1997: an exploratory study. International Journal of Islamic Financial Services, 1(3).

Saridona, R., \& Cahyandito, M. F. (2015). Social performance of Indonesia Islamic banking: analysis of Islamic social reporting index. In the 1st International Conference on Economics and Banking (pp. 194-200).

Setiawan, A. B. (2009). Kesehatan finansial dan kinerja sosial bank umum syariah di Indonesia. Paper presented at National Joint Seminar Between Magister Bisnis Keuangan Islam Universitas Paramadina and Ikatan Ahli Ekonomi Islam (IAEI) Pusat dan Masyarakat Ekonomi Shariah (MES). (pp. 1-55). 